\title{
ETHICAL AND SOCIAL COMMITMENT IN THE TEACHING PLAN OF NURSING EDUCATION
}

\author{
Daiana Kloh', Margarete Maria de Lima², Kenya Schmidt Reibnitz ${ }^{3}$
}

${ }^{1}$ Ph.D. student at the Nursing Graduate Program of the Federal University of Santa Catarina. CAPES Scholarship. Santa Catarina, Brazil. E-mail: daianakhloh@gmail.com

${ }^{2}$ Ph.D. student at the Nursing Graduate Program of the Federal University of Santa Catarina. CNPq scholarship. Santa Catarina, Brazil. E-mail: margaretelima2@gmail.com

${ }^{3}$ Ph.D. in Nursing. Professor of the Nursing Department of the Federal University of Santa Catarina. Santa Catarina, Brazil. E-mail: kenya@ccs.ufsc.br

\begin{abstract}
This study focuses on the ethical and social commitment in nursing education and its impact on the development of the teaching plan, with the viewpoint that this theoretical reflection can contribute to awaken the interrelationship of the teaching plan and ethical and social commitment in college-level courses. It is assumed that the concept of ethics adapts to the values relative to each time and place, being considered an essential element for the comprehensive education of human beings. In order for education to be anchored in actions in accordance with social, ethical and professional commitment, ethical principles should permeate the curriculum content, and be present in teaching positions that involve interpersonal relationships and evaluation procedures.
\end{abstract}

KEYWORDS: Education, higher. Ethics. Nursing.

\section{COMPROMISSO ÉTICO-SOCIAL NA PROPOSTA PEDAGÓGICA DA FORMAÇÃO EM ENFERMAGEM}

RESUMO: Esta reflexão enfoca o compromisso ético-social na formação em enfermagem e suas repercussões no desenvolvimento da proposta pedagógica, na perspectiva de que esta reflexão teórica possa contribuir para o despertar da inter-relação da proposta pedagógica com o compromisso ético-social nos cursos de graduação. Considera-se que o conceito de ética vai adequando-se aos valores relativos a cada época e lugar, sendo considerada como um elemento essencial para a formação integral do ser humano. Para que a formação seja ancorada em ações de acordo com o compromisso ético-social e profissional, os princípios éticos devem permear os conteúdos curriculares, estar presentes nas posturas pedagógicas envolvendo as relações interpessoais e os processos de avaliação.

PALAVRAS CHAVE: Educação superior. Ética. Enfermagem.

\section{COMPROMISO ÉTICO-SOCIAL EN LA PROPUESTA PEDAGÓGICA DE LA FORMACIÓN EN ENFERMERÍA}

RESUMEN: Esta reflexión enfoca el compromiso ético-social en la formación de enfermería y su impacto en el desarrollo de la propuesta pedagógica, en la perspectiva de que esta reflexión teórica puede contribuir para el despertar de la interrelación de la propuesta pedagógica con el compromiso ético-social en los cursos de graduación. Se considera que el concepto de ética va adecuándose a los valores relativos de cada época y lugar, siendo considerado como un elemento esencial para la formación integral del ser humano. Para que la formación sea sustentada en acciones en concordancia con el compromiso ético-social y profesional, los principios éticos deben impregnar los contenidos curriculares, estar presentes en las posturas pedagogías, involucrando las relaciones interpersonales y los procesos de evaluación.

PALABRAS CLAVE: Educación superior. Ética. Enfermería. 


\section{INTRODUCTION}

This discussion addresses the proposed changes to health education, motivated mainly by the Brazilian National Curriculum Guidelines (NCGs), which are reflected in the development of the mission of educational institutions, implying an ethical and social commitment to education and health.

Ethical and social commitment requires rethinking, overcoming and even reconstructing the way content is taught and learned in the classroom, and requires teaching support for students and professors, willingness to revisit the interpersonal relationships established in the context of education, as well as a critical look at the evaluations of higher education. It is the responsibility of educational institutions to train professionals capable of standing out in their field of work, acting in accordance with the ethical principles of the profession, and especially to consider themselves jointly responsible for the actions of citizenship, and able to act critically and proactively in the health care system. ${ }^{1}$

To solidify ethical and social commitment, it is presumed that educational institutions significantly treat content that enables future professionals to meet the needs of the population, come closer to the reality of health care, and develop strategies aimed at cooperation and mutual respect, both in the academic/population and professor/student relationship.

This ethical and social commitment also involves learning evaluations that enable students and professors to critically reflect upon how they are building their educational process, allowing them to overcome weaknesses and praise the positive points of the players involved in the process of teaching and learning. From this perspective, it is understandable that the educational practice is not measured by immediate manifestations of knowledge and skills acquired, being unacceptable to determine the quality of teaching from observable products in the short term. ${ }^{2}$

Educational institutions must assume the role of inquiring into the ethical principles that sustain society, delving into relationships of human submission and exploitation. We believe that the teaching space does not end in the classroom, but is contextualized in spaces of work, in the everyday of schools, and in the intentionality of teaching practice concerned with subjectivity, ethics and identities. ${ }^{3}$
The concept of ethics adapts to the values of each time and place, and it is an essential element for the comprehensive education of human beings. In the teaching plan, we are consigned to respect and value human nature, in which the professor assumes the role of mediating/facilitating the development of autonomy and constitution of subjectivity of the student. ${ }^{4}$ It is from this ethical education that the professor, during his or her act of educating, integrates technical and scientific training of students with the fundamental knowledge to exercise their citizenship. ${ }^{5}$

These reflections challenged us to question: are we getting closer to the ethical and social commitment presented by the NCGs? Is there teaching support for our professors and students? Do we think of the principle of comprehensive care within academia, aimed at professors and students, or do we only consider it in the professional-user relationship? Does the evaluation process respect different learning times? How long will we use the summative evaluation process without considering the learning process of each subject in the education process?

These questions are often confronted in academia, however, the reflection that promotes changes in the teaching practice has been developing slowly. Students and professors distance themselves from possibilities for dialogue, understanding the difficulties of the other, the larger view of the human being, and the perception of comprehensiveness in the relationships established in the education process.

The aim of this study is not to answer all of the questions above, but to awaken concerns from the perspective that theoretical reflection on the subject can contribute to the awakening of ethical and social commitment in the teaching plan of undergraduate nursing courses. It is our responsibility to refrain from judgment, not because the issues raised above are extremely delicate, and sometimes even controversial, but out of respect for the choice of each individual.

\section{ETHICS AS A CROSS-CUTTING AXIS IN CURRICULUM CONTENT}

The National Curriculum Guidelines for Nursing Courses (NCG/Nursing) refers to ethics in four specific areas: skills and abilities, specific skills and abilities, curriculum content and course organization. In all of these, ethics is clearly shown to be an essential component in nursing educa- 
tion. In curriculum content, it appears directed at nursing practice according to professional ethics. ${ }^{6}$

Nevertheless, after eleven years of implementation of the NCGs, delays by educational institutions to train professionals to develop their work in accordance with social, ethical and professional commitment are still perceived. This statement can be verified in both the development of practical activities and the development of curriculum content, environments in which ethical commitment becomes invisible to the eyes of the players involved in the teaching and learning process. The invisibility of ethical commitment and practice of ethics may be related to the image of ethics itself in curricula, in which it is situated in a framework of insignificance, sometimes appearing as an elective subject and in multidisciplinary seminars. ${ }^{7}$ The explanation for this lies in traditional scientific and medical education, which focuses more on techniques than on ethics and, consequently, there are few professors in this discipline.

It is worth noting that we do not intend to ignore the changes taking place in education, but to recognize them and launch new expectations, so that future professionals develop their work based on the principles of ethics and solidarity. Yet we must urgently train professionals that meet the needs of society. To this end, more creative, dialogical methods should be considered to portray the possibility of reflective encounter between the subjects involved in this dialogical possibility, among which we highlight the professor and student.?

It is also from ethics that education should be solidified as an intentional investment into the consolidation of educational plans mediated by reality, encompassing the human being as a social, political and historical being. Hence, the "investment in education and professional work by the educator cannot be reduced to a supposed purely technical qualification." 8:120

Real and direct experiences, experienced in daily personal and professional life, in which ethics and ethical practice are a reality, should permeate the development of curriculum content, establishing a dialogical relationship between students and professors throughout the education process. Therefore, a single subject cannot provide all of the necessary resources for such a goal to be attained, because we are talking about a long-term, complex and expansive process. ${ }^{9}$

We should not delude ourselves by believing that the domain of knowledge and skills ensures humanitarian development in students, and that their professors are sensitized to this theme. This is because ethics education is a necessity of the human learning process, which cannot be reduced to a simple act of production, organization and distribution of knowledge and skills. "Human education will only be complete if accompanied by the development of principles of conduct which can be recognized as universally valid."10:252

Another difficulty for the development of ethical thought is the memorization of content. Memorization does not allow the student to perform any cognitive act, since the object of his or her learning is often regarded as the property of the professor, and therefore not constructed from the critical thinking of both. ${ }^{11}$

Thus, individuals are educated to be intimidated by reflection, awareness of the world and their ethical and social commitment. The greater the problematization ${ }^{11}$ and meaningful learning provided to students, as beings who are part of and in the world, the more they will feel challenged. Challenges impel us to search for answers, because the obstacle is perceived as one problem interlocked with others, on a whole/entire plane, not as something petrified or finished. The resulting understanding tends to become increasingly critical and not alienated.

\section{ETHICS, DIALOGUE AND TEACHING SUPPORT IN THE TEACHING AND LEARNING PROCESS}

The implementation of the NCGs in nursing required and still requires changes in the education process, if the aim is to train professionals to act with "a sense of social responsibility and commitment to citizenship, as a promoter of the comprehensive health of human beings, based on principles of the Brazilian Health Care Reform and the Unified Health System (SUS, as per its acronym in Portuguese). ${ }^{12: 367}$

In teaching practice, there is change with respect to the way in which students and professors act. The student ceases to lack in content, and the professor ceases to be the holder of knowledge, when this dialogical relationship between teaching and learning is established, and the focus becomes learning. In this relationship, ethics comes to be understood as a reference to the other, keeping in mind that morality is not based on sameness, but on difference. ${ }^{13}$

Thus, the professor relates with "double ethics: as an educator, in the role of leading, influenc- 
ing and deciding on the conduct of others; and as a professional with the task of teaching, training and qualifying others to be professionals." 2:116 Nevertheless, it is worth noting that the ethical behavior of professors is rarely the subject of research, and there is no existing code of ethics governing their activities. This may be linked to the expectation that professors, by nature of their profession, are aware of the moral aspect of their work as conveyor of morality in the education of students. ${ }^{2}$

In this context, conflict zones that require more of both parties are often created, requiring greater openness by professors to dialogue, and greater participation by students. In this moment, the weaknesses and strengths of each, as well as the overload of both, are revealed. For instance, overload on the student who, by not being participatory and open to dialogue, feels unable to understand a specific issue. On the professor, by having difficulty in adopting strategies that optimize dialogue between him/herself and the class.

By wishing to validate the sense of social responsibility and commitment to citizenship in the health care education process, we must democratize teaching relations through dialogue, as by "living in respectful openness to others and, from time to time, according to the moment, to take the very practice of openness to the other as an object of critical reflection, should be part of the teaching adventure. The ethical reasoning of the openness, its political foundation, its educational reference; the beauty in it as viability of the dialogue." 5:153

At the same time, we can no longer continue to be blind to students who fail year after year, or who have greater difficulty learning. Thus, the need arises to provide educational support to professors and students to deal with this new attitude of "learning" and teaching; at the same time as questions are raised about the preparation of professors to provide educational support, and if the educational institution has an interest and structure for this educational support.

The issues that were aforementioned become relevant when considering which methodological plan is desired, if it requires direct contact with various teaching scenarios in health care; which strategies can be adopted for the development of autonomy, and critical and reflective thinking during important actions in the teaching process.

That is why we need to build and rethink ways of working better with health care, and of developing public health care policies according to local and regional requirements. One of the strat- egies is to unite teaching with service, in which approximation with the reality of health care encourages the formation of new professionals with knowledge of the political and social reality, service, committed to society, questioning it, and seeking practical solutions to its problems.

Students and professors engage with the problems of health care, and concurrently work the weaknesses of teaching, such as understanding of the current health care system; because they are close to the system, there is an involvement that requires both reading, interest, reflections, overcoming challenges and companionship/collegiality.

At the same time, the transformative praxis is built, as it is believed that the student bases his/her action on updated and problematized theoretical content that contributes to modify and innovate the space of health care services. "Thus, the academic develops skills according to individuality, the collective and organization of the service into which he or she is inserted."14:176

\section{INTERPERSONALRELATIONSHIPBASED ON ETHICS AND COMPREHENSIVENESS}

The new pedagogies suggested for the education of ethical subjects committed to political and social issues involve a complex process, with variables related to the curriculum content, the teaching and learning process, the evaluation process and the relationships established in the context of education.

In this perspective, we need to reflect on how the social actors involved in the context of the education relate, and what strategies they adopt in their everyday practices so that interpersonal relationships are guided by ethics and integrity. To think of these two principles implies revisiting the teaching content and positions in educational institutions, because in order for ethics and integrity to materialize in interpersonal relationships during the education process, it is crucial that there is an intentionality on the part of those involved in this context, as well as institutional support so that they materialize in academic practice.

It is also important to consider if they are "teaching" and "learning" to develop ethical thinking simply in the professional-user relationship, or if this extends to the professor-student relationship. Such a statement by itself already answers; after all, if something is learned about ethics directed only to the user, it is a sign that it was not learned to its fullest. For instance, the 
issue of comprehensive care, which is sustained from the ethical and social commitment, solidarity, interdisciplinarity, etc.

In the education process, comprehensiveness applied in the professor-student relationship becomes a prerequisite for the construction of the professional identity of future nurses, in line with the principles of the SUS. In order to have a professional who understands the user as a comprehensive subject, this needs to be developed during his/her education as a subject, because it is in this educational process that the future nurse that we want to train is constructed or deconstructed. ${ }^{15}$ In this perspective, comprehensiveness in the professor-student relationship becomes a crosscutting component for care in the perspective of comprehensiveness and ethical, political and social commitment.

The principle of comprehensiveness is hardly seen in professor-professor, studentprofessor and student-student relationships. But why is that? Did we fail to apply it by ignoring that comprehensiveness can also be a principle of interpersonal relationships? Or are we talking about comprehensiveness with different meanings? How can comprehensiveness be taught in the professional-population relationship without experiencing it in other relationships in the field of education?

These questions reflect the need to delve into the theme, for us to come closer to a teaching practice anchored in the principles of comprehensiveness and ethical and social commitment.

The teaching practices adopted reflect the ideology of the context in which they are inserted, based on a solid conception of how one wants to teach/learn so that the transformation of reality occurs. But in order for this to take place, education must be guided by creativity, enabling reflection and action that is critical of reality, committed to social transformation. In addition, the educational model should favor synchrony between thinking and feeling, between the development of the capacity for abstraction and the distinct characteristics of personality. ${ }^{3}$ Thus, by experiencing an education committed to social transformation, based on comprehensiveness and the practice of ethics in interpersonal relationships, future nurses have the opportunity to acquire skills and abilities to establish interpersonal relationships based on these principles in their daily professional life.

We believe in the existence of many possibilities applicable to the interpersonal relationships of the subjects involved in the education process. Nevertheless, we emphasize that in order for a transformation process to take place guided by ethics, the social and comprehensiveness, it is essential that those involved in the education process - and here we refer to professors, students and professionals from other support networks have the will and courage to want to change, to do something different, so that future professionals can commit to the needs of the population, with ethical and social commitment to comprehensiveness in the interpersonal relationships established in different contexts.

Incorporating the ethical dimension into the teaching relationship favors the formation of epistemologically competent professionals who are simultaneously reflective and flexible, and simultaneously sensitizes professors to the plight of students and respect for their diversity. This incorporation in teaching relationships generates hope for change in academia as well as society, in which sensitivity reflects the fundamentally political nature of ethics as establishing a goal to be attained. ${ }^{4}$

In this context, the role of the professor is defined as one who acquires knowledge through the act of teaching knowledge. Thus, education serves as the foundation of social change when it does not intend to adapt, thereby killing its possibility for action and thinking. ${ }^{16}$

\section{PROCESS OF ETHICAL, POLITICAL AND SOCIAL EVALUATION}

To reflect on the evaluation process, we take ethical individualism as the basis, in which, at the same time that individuals develop their autonomy, they generate the privatization of ethics. This becomes secular and individualized with the weakening of responsibility and solidarity, a distance between individual ethics and the ethics of the city is imposed, which contributes to the disintegration of traditional communities. ${ }^{17}$

In this context, the assessment becomes part of the teaching work developed in the different scenarios of the teaching-learning process, culturally gaining a prominent place among the countless expressions of the teaching work, frequently acquiring an excessive centrality. ${ }^{18}$

The evaluation process may become fragmented when restricting it to cognitive aspects, skills and dexterity, which may have consequences for the professional practice of the egress. This 
fragmentation of the evaluation process can generate professional failures due to the unpreparedness of these subjects, or the incompatibility of their values with the ethical and social attitude needed for the professional work. ${ }^{18}$

We believe that the evaluation process should be based on principles such as: dialogue, democracy, solidarity, inclusion, participation and justice. When considering that the evaluation process must be dialogical, this means that relationships are established between equal subjects, with the same rights and duties, as citizens. Thus, the dialog promotes a relationship of mutual respect. Justice as an evaluative principle allows the professor to appreciate what the student learned, rather than what he or she does not know.

To recognize the evaluation as a process of action-reflection-action, interwoven in the daily practice of teaching, constructed by students and professors, is the first step in the evaluation process and helps to gradually overcome the difficulties encountered in the teaching-learning process, constructing subjectivities in a mutual and interdisciplinary manner. Thus, it loses its character as a measurement of content learned by the student, turning into a process of reinforcement of learning, together with the student. The evaluation process must be imbued with a commitment to education that is inseparable from the human being and the professional.

This initiative on the discussion of the evaluation process is not current/new; there is much discussion about evaluation in education, with different evaluation plans based on the teaching framework, sometimes antagonistic regarding its process and outcome. Thus, there are various evaluation strategies, but that which we defend as an ethical principle needs to provide students with insights about their education process, starting from a critical and reflective view from both the professor and the student.

This is based on the principle that the future professional, when entering the work market, will develop evaluation practices in health, whether related to care, management or service. Thus, the future professional will need to have experienced, during his or her education practices, democratic evaluation, based on dialogue, which consider the context of each person or group involved in the evaluation process, and which allows for reflection on the context in which they were performed. Thus, future professionals will be better able to incorporate dialogue, and democratic and reflective attitudes into their evaluation practices, because they experienced these practices during their education process.

Regardless of the scenario where the evaluation is experienced, some assumptions are common to the process. Some authors report that the evaluation process can be a tool in processes of social mediation when it aggregates facilitating aspects in social communication, stimulating dialogue and the reconstruction of reality through the various views of the stakeholders involved in the evaluation, including those with less voice. They also advocate the encouragement of building autonomy and citizenship of the subjects. ${ }^{19}$

Evaluation in the educational process shows some singularities which must be observed when its plan is an evaluation committed to the ethical and social sphere. It is a strategy of refeeding the education process, with systematic monitoring of the evolution of the student in building his or her knowledge, has the function of guiding and (re) defining the trajectory and reorienting the choice of learning experiences, because it assesses the methodologies and tools employed in the education process, analyzes the goals of teaching and learning, taking into account the multidimensional nature of the human being. It also reveals how professors and other players involved in the educational process are performing, and provides data to assess the curricular effectiveness in the face of social and cultural needs. ${ }^{3}$

In this sense, it is also necessary to consider that professors and students are historical and social beings and, as such, they are capable of comparing, valuing, intervening, choosing, deciding and breaking, being therefore ethical subjects. This is why the educational experience cannot be purely technical; if this occurs, it will be belittling what is fundamentally human in the educational process: its educational nature. ${ }^{5}$ Just as we cannot forget that the ethical object in the development of teaching in the field of health is in a process of consolidation $^{20}$ in educational institutions.

When considering the arguments espoused here, we understand the evaluation process as something complex that requires clarification on how we understand and apply the evaluation in health education. If we perceive it as a punitive, authoritative process that assesses the knowledge not acquired by the student, we will continue to observe the bleak scenario of corridors, which presents the classification levels among students. To modify this scenario, it is critical to understand 
and apply the evaluation using the dialogical principles, and regard it as a process that perceives the human being in its complexity, with different learning times, particularities, and diverse social and cultural realities.

\section{FINAL CONSIDERATIONS}

The education of ethical subjects requires social and political commitment by educational institutions to review the teaching practices and positions taken by their professors in face of the school and society. Thus, we sought to reflect on the needs of real changes in teaching plans, because curricular changes made only in institutional documents will not do anything if they are not incorporated into teaching practice and the daily lives of the players involved in the act of teaching and learning.

Strategies for the education of ethical subjects are strongly linked to approximation to reality, with the social context in which we live, with questioning, meaningful learning and understanding that everyone is responsible for their education. Schools compete to offer approximation to reality, and from this, reflection, followed by reflection of the actions, which results in professionals aware of their rights and duties towards society, in which respect and full view of the educator and educated subject prevail.

Thus, we believe that ethical and social commitment in the teaching plan is present when it provides the interlacing of curricular content that articulates the various situations of the social and health context, with evaluation processes that encourage reflection, mutual respect and appreciation of the subjects.

This perspective opens the possibility of (re) construction in the education of health professionals, more aware of their commitment to society and especially to life. In which respect for the patient and the student in the education process become significant examples of an action of care and teaching that respects the individuality, multiplicity and complexity of human beings. Thus, we are just steps away from the consolidation and effectiveness of the NCGs in nursing and health care, as well as the principles that guide the SUS.

\section{REFERENCES}

1. Ramos FRS, Borges LM, Brehmer LCF, Silveira LR. Formação ética do enfermeiro: indicativos de mudança na percepção de professores. Acta Paul Enferm. 2011; 24(4):485-92.
2. Vasconcellos MMM. Avaliação e ética. Londrina (PR):UEL, 2002.

3. Reibnitz, KS, Prado ML. Inovação e educação em enfermagem. Florianópolis (SC): Cidade Futura, 2006.

4. Cardoso WS, Gadelha L. Refletindo a ética na formação do educador. In: Anais do $5^{\circ}$ Colóquio Internacional Paulo Freire, 2005 Set 19-22; Recife (PE): Centro Paulo Freire: estudos e pesquisas; 2005.

5. Freire P. Pedagogia da autonomia: saberes necessários à prática educativa. $43^{\mathrm{a}} \mathrm{ed}$. Rio de Janeiro (RJ): Paz e Terra; 2011.

6. Ministério da Educação e Cultura (BR). Resolução CNE/CES n. 03 de 07 de novembro de 2001. Dispõe sobre Diretrizes Curriculares Nacionais do Curso de Graduação em Enfermagem. Diário Oficial da União, Brasília (DF), 9 nov. 2001a. Seção 1:37.

7. Erdmann AL, Ramos FR, Reibnitz KS, Prado ML. Educação em bioética: desafios para a formação crítico-criativa dos profissionais de enfermagem. In: Pessino L, Barchifontaine $\mathrm{CP}$, organizadores. Bioética e longevidade humana. São Paulo (SP): Ed. Loyola; 2006.

8. Severino AJ. Educação e universidade: o conhecimento e construção da cidadania. Rev Interfa Comunic Saúde Educ. 2002 Fev; 6(10):117-24.

9. Ferreira HM, Ramos LH. Diretrizes curriculares para o ensino da ética na graduação em enfermagem. Acta Paul Enferm. 2006 Jul-Ago;19(3):328-31.

10. Rodrigues N. Educação: da formação humana à construção do sujeito ético. Educ Soc. 2001 Out; 22(76):232-57.

11. Freire P. Pedagogia do oprimido. $50^{\mathrm{a}}$ ed. Rio de Janeiro (RJ): Paz e Terra; 2011.

12. Fernandes JD, Rosa DOS, Vieira TT, Sadigursky D. Dimensão ética do fazer cotidiano no processo de formação do enfermeiro. Rev Esc Enferm USP. 2008; 42(2):396-403.

13. Candiotto C. Algumas aproximações entre ética e ensino superior. Rev Diálogo Educ. 2001 Jul-Dez; 2(4):61-5.

14. Benito GAV, Tristão KM, Paula ACSF, Santos MA, Ataide LJ, Lima RCD.. Desenvolvimento de competências gerais durante o estágio supervisionado. Rev Bras Enferm. 2012 Jan-Fev; 65(1):172-8.

15. Lima ML, Reibnitz KS, Prado ML, Kloh D. Integralidade como princípio pedagógico na formação do enfermeiro. Texto Contexto Enferm. 2013 Jan-Mar; 22(1):106-13.

16. Freire P. Pedagogia da indignação. São Paulo (SP): UNESP; 2000.

17. Morin E. O método 6: ética. Porto Alegre (RS): Sulina; 2005.

18. Braccialli LAD, Oliveira MAC. Concepções de avaliação de desempenho em um currículo 
orientado por competência. Rev Esc Enferm USP. 2011; 45(5):1221-8.

19. Silva Junior AG, Alvez AA, Machado MRC, Lima RH, Nascimento-Silva VM. Práticas avaliativas em saúde, mediação e integralidade: outras possibilidades. In: Pinheiro R, Silva Junior AG, organizadores. Cidadania no cuidado: o universal e o comum na integralidade das ações de saúde. Rio de Janeiro (RJ): IMS/UERJ, CEPESC; 2011.

20. Caregnato RCA, Martini RMF, Mutti RMV. Questão ético-moral na formação dos enfermeiros e médicos: efeitos de sentidos nos discursos docentes. Texto Contexto Enferm. 2009 Out-Dez; 18(4):713-21. 